Bangladesh J. Bot. 39(1): 29-36, 2010 (June)

\title{
SEASONALITY AND DIVERSITY OF EPIPELIC DIATOMS IN TWO WETLANDS OF BANGLADESH
}

\author{
Khurshid Nahar ${ }^{1}$, Moniruzzaman KhONdKer* and Munira Sultana ${ }^{2}$ \\ Department of Botany, University of Dhaka, Dhaka-1000, Bangladesh
}

Key words: Epipelic diatoms, Sitlai Beel, Wetlands, Melosira, Bangladesh

\begin{abstract}
Seasonality and composition of epipelic diatom community were studied for two years in two wetlands of Bangladesh namely, Joysagar and Sitlai Beel. A total 73 diatom taxa were recorded. The average density of epipelic diatom was higher in Sitlai Beel $\left(52.97 \times 10^{4} / \mathrm{g}\right.$ sediment $)$ than in the Joysagar $\left(3.92 \times 10^{4} / \mathrm{g}\right.$ sediment). The epipelic diatom community of Joysagar was dominated by the species of Melosira, Synedra, Navicula, Pinnularia, Gomphonema, and Nitzschia, whereas Melosira, Navicula, Pinnularia, Cymbella and Gomphonema dominated in Sitlai Beel. Melosira granulata, Navicula americana, Pinnularia major, and Gomphonema lanceolatum were dominant and expressed distinct seasonality in both wetlands. The concentration of soluble reactive silicate of water and the average density of epipelic diatom did not express any significant relation in both of the water bodies. The concentration of phytoplankton chl $a$ had a positive relationship with epipelic diatoms and was significant in Sitlai Beel.
\end{abstract}

\section{Introduction}

Epipelic diatoms are important primary producers and key food source for benthic organisms (Daume et al. 1999, Beltrones and Romero 2001) in shallow aquatic environments. Moreover, they contribute in carbon cycling (Hecky and Hesslein 1995, Barranguet 1997). Several variables such as sediment type (Amspoker and McIntire 1986), nutrient availability (Agatz et al. 1999), salinity (Underwood et al. 1998) of a water body can affect the distribution and diversity of epipelic diatom communities. Compared to benthic macroinvertebrates, diatoms are considered more sensitive indicator of water chemistry owing to their shorter life cycle and nature as primary producer (Steinberg and Schiefele 1988). They have been found to be useful for river monitoring purposes (Eloranta and Andersson 1998). Seasonality and water quality alterations have been linked to changes in aquatic biota and each species of diatom has a specific distribution range and tolerance for environmental variables.

Bangladesh possesses enormous area of wetlands and those have an ecological, socio-cultural, and economical importance. The haors, baors, beels and jheels are of fluvial origin and are commonly identified as freshwater wetlands and regarded as valuable fish and wild life habitats. The ecology of epipelic diatoms is less well understood than their pelagic counterparts in various limnological study of Bangladesh. The present study includes spatial and temporal variations in species composition of epipelic diatoms of Joysagar pond and Sitlai Beel

\section{Materials and Methods}

Two wetlands, namely Joysagar pond and Sitlai Beel in the district of Sirajganj, Bangladesh were selected for this study. Joysagar pond $\left(24^{\circ} 28^{\prime} 40^{\prime \prime}-24^{\circ} 28^{\prime} 50^{\prime \prime} \mathrm{E}\right.$ and $\left.89^{\circ} 25^{\prime} 24^{\prime \prime}-89^{\circ} 25^{\prime} 42^{\prime \prime} \mathrm{N}\right)$ is about $0.226 \mathrm{~km}^{2}$ in area and up to $2.13 \mathrm{~m}$ deep during monsoon. On the other hand, Sitlai Beel $\left(24^{\circ} 28^{\prime} 10^{\prime \prime} \mathrm{E}\right.$ and $\left.89^{\circ} 26^{\prime} 30^{\prime \prime} \mathrm{N}\right)$ has an area of $0.04 \mathrm{~km}^{2}$. Fertilization is done by chemical fertilizer in

*Corresponding author. ${ }^{1}$ Department of Botany, Jagannath University, Dhaka, Bangladesh. ${ }^{2}$ Institute of Freshwater Ecology and Inland Fisheries, 301, Müggelseedam, 12587 Berlin, Germany. 
both the water bodies for aquaculture. Besides, the water of Sitlai Beel is also used for domestic purposes by villagers. Samples for the present study were collected bi-monthly for a period from June, 1995 to May, 1997. The average values of some physical and chemical variables of the wetlands are presented at Table 1 .

Table 1. Physico-chemical states of the studied wetlands.

\begin{tabular}{lcc}
\hline Variables & Joysagar & Sitlai Beel \\
\hline Air temperature $\left({ }^{\circ} \mathrm{C}\right)$ & $29.90 \pm 9.30$ & $21.70 \pm 2.60$ \\
Water temperature $\left({ }^{\circ} \mathrm{C}\right)$ & $27.40 \pm 4.10$ & $28.50 \pm 4.30$ \\
Maximum depth $(\mathrm{Zs})(\mathrm{cm})$ & $14.10 \pm 1.70$ & $14.90 \pm 2.00$ \\
$\mathrm{pH}$ & $7.40 \pm 0.70$ & $7.50 \pm 0.70$ \\
Alkalinity $(\mathrm{meq} / \mathrm{l})$ & $0.66 \pm 0.10$ & $0.44 \pm 0.12$ \\
Conductivity $(\mu \mathrm{S} / \mathrm{cm})$ & $109.20 \pm 27.40$ & $85.60 \pm 20.70$ \\
Soluble reactive silicate $(\mathrm{SRS})(\mathrm{mg} / \mathrm{l})$ & $11.43 \pm 0.61$ & $21.00 \pm 0.80$ \\
Soluble reactive phosphorus $(\mathrm{SRP})(\mu \mathrm{g} / \mathrm{l})$ & $79.87 \pm 9.95$ & $220.18 \pm 15.66$ \\
Total phosphorus $(\mathrm{TP})(\mu \mathrm{g} / \mathrm{l})$ & $254.00 \pm 82.20$ & $458.70 \pm 278.90$ \\
$\mathrm{NO}_{3}$-N $(\mu \mathrm{g} / \mathrm{l})$ & $97.70 \pm 52.10$ & $127.20 \pm 76.80$ \\
Phytoplankton chl $a(\mu \mathrm{g} / \mathrm{l})$ & $174.10 \pm 93.00$ & $97.90 \pm 58.30$ \\
\hline
\end{tabular}

Duplicate water samples were collected from five stations of each wetland by a Schindlers sampler (5 L capacity) and taken into screw capped $500 \mathrm{ml}$ capacity polystyrene bottles for chemical analysis. A known volume of water was filtered through a Whatman GF/C filter paper by Sartorius vacuum filtration pump (GMBh, Göttingen, Germany). Chl $a$ was extracted from the Whatman GF/C filter paper with hot ethanol, described by Marker et al. (1980), and the concentration was determined following APHA (1989). The filtered water was used for the analysis of soluble reactive silicate (Golterman et al. 1978).

A PVC pipe (length $30 \mathrm{~cm}$ and diameter $5 \mathrm{~cm}$ ) was used to collect the sediment sample for epipelic diatom analysis. The pipe was inserted manually in the soft mud with the help of a diver and made air tight by putting a rubber cork at the other end of the pipe. It made the pipe air tight. It was then pulled out from the sediment and a second rubber cork was put and pushed slowly from the bottom end of the pipe. The water above sediment in the tube was sucked out by using the force of gravity. A $0.5 \mathrm{~cm}$ thin section of the top most sediment was then cut with the help of a piece of galvanized metal sheet. The piece of wet sediment was kept in a screw capped wide mouthed plastic jar (100 ml capacity) and preserved with $4 \%$ formalin. Diatom frustules were cleaned using 30\% hydrogen peroxide and 30\% potassium dichromate as described by Van der Werff (1958) and preserved in a screw capped glass vials for quantitative and qualitative analysis. The number of valves of each species was counted for each sample. Diatoms were identified using Hustedt (1930), Germain (1981), Islam and Haroon (1975), Foged (1976), Federovich (1980) and Tolonen et al. (1986).

All data were checked for the assumption of normal distributions and homogeneity of the variances before statistical analyses. The regression analysis of SRS and phytoplankton chl $a$ with the density of epipelic diatom was performed using MS Excel. One-way ANOVAs were used (STATISTICA, version 5) to determine statistical significance of SRS and chl $a$ with density of epipelic diatom as the main factor and to find statistical differences of the density of diatom cells between the wetlands. 


\section{Results and Discussion}

A total of 73 diatom taxa were recorded from the two studied water bodies, of which solely 12 taxa occurred in Joysagar and 21 taxa occurred in Sitlai Beel. Forty taxa of diatom were common for both the Joysagar and Sitlai Beel (Table 2). Number of total mean diatom frustules in Joysagar and Sitlai Beel are plotted in Fig. 1. The average density of epipelic diatom was significantly higher (one-way ANOVA, $\mathrm{p}>0.001)$ in Sitlai Beel $\left(52.97 \times 10^{4} / \mathrm{g}\right.$ sediment) than in the Joysagar $\left(3.92 \times 10^{4} / g\right.$ sediment) (Fig. 1). In the first year (1995-1996) of the observation, lowest diatom cell density $\left(1.6 \times 10^{4} / \mathrm{g}\right.$ sediment in Joysagar and $32.1 \times 10^{4} / \mathrm{g}$ sediment in Sitlai Beel $)$ was observed in June' 95 whereas the highest density $\left(12 \times 10^{4} / \mathrm{g}\right.$ sediment in Joysagar and $71.9 \times 10^{4} / \mathrm{g}$ sediment in Sitlai Beel) was attained in April' 96 for both study sites (Fig. 1). In the second year (1996-97), highest density of diatom frustules was recorded in March'97 for both the studied sites $\left(13.2 \times 10^{4} / \mathrm{g}\right.$ sediment in Joysagar and $70 \times 10^{4} / \mathrm{g}$ sediment in Sitlai Beel $)$.

Table 2. List of benthic diatom taxa recorded from both Joysagar and Sitlai Beel.

\begin{tabular}{|c|c|}
\hline Joysagar & Sitlai Beel \\
\hline Coscinodiscaceae & Coscinodiscaceae \\
\hline Cyclotella meneghiniana Kütz. & Cyclotella meneghiniana Kütz. \\
\hline Cyclotella stelligera Cleve et Grun. & Cyclotella stelligera Cleve et Grun. \\
\hline Melosira granulata (Ehr.) Ralfs & Melosira distans var. alpigina Grun. \\
\hline Melosira granulata var. curva Grun. & Melosira granulata (Ehr.) Ralfs \\
\hline Fragilariaceae & Melosira granulata var. angustissima Mull. \\
\hline Asterionella formosa Hasall. & Fragilariaceae \\
\hline Fragilaria intermedia Grun. & Asterionella formosa Hasall. \\
\hline Fragilaria virescens Ralfs & Fragilaria intermedia Grun. \\
\hline Synedra ulna (Nitz.) Ehr. & Fragilaria virescens Ralfs \\
\hline Synedra vaucheriae Kütz. & Synedra rumpens var. familiaris Kütz. \\
\hline Synnedra rumpens var. familiaris Kütz. & Synedra ulna (Nitz.) Ehr. \\
\hline Naviculaceae & Naviculaceae \\
\hline Amphora comutata Grun. & Amphora commutata Grun. \\
\hline Cymbella turgida (Gregory) Cleve & Amphora ovalis var. libyca (Ehr.) Cleve \\
\hline Diploneis ovalis (Hilse) Cleve & Caloneis silicula (Ehr.) Cleve \\
\hline Gomphonema acuminatum Ehr. & Cymbella tumida (Bréb.) van Heurek \\
\hline Gomphonema augur Ehr. & Cymbella turgida (Gregory) Cleve \\
\hline Gomphonema lanceolatum (Greg.) Cleve & Cymbella ventricosa Kütz. \\
\hline Gomphonema longiceps Ehr. & Diploneis ovalis (Hilse) Cleve \\
\hline Gomphonema subtile Ehr. & Gomphonema acuminatum Ehr. \\
\hline Navicula mutica Kütz. & Gomphonema augur Ehr. \\
\hline Navicula americana Ehr. & Gomphonema helveticum Brun. \\
\hline Navicula cuspidata Kütz. & Gomphonema lanceolatum (Greg.) Cleve \\
\hline Navicula cuspidata Kütz. var. heribaudii Peragallo & Gomphonema subtile Ehr. \\
\hline Navicula grimmei Krasske & Navicula muctica Kütz. \\
\hline Navicula laevissima Kütz. & Navicula pupula Kütz. var. capitata Hust. \\
\hline
\end{tabular}


(Contd.)

\begin{tabular}{|c|c|}
\hline Navicula pupula Kütz. & Neidium binodis (Ehr.) Cleve \\
\hline Neidium iridis (Ehr.) Cleve & Neidium irridis (Ehr.) Cleve \\
\hline Pinnularia krookei (Grun.) Cleve & Pinnulaira krookei (Grun.) Cleve \\
\hline Pinnularia acrosphaeria Bréb. & Pinnulaira major (Kütz.) Cleve \\
\hline Pinnularia acrosphaeria Bréb. var. laevis Cleve & Pinnularia acrosphaeria Bréb. \\
\hline Pinnularia braunii (Grun.) Cleve & Pinnularia braunii (Grun.) Cleve \\
\hline Pinnularia major (Kütz.) Cleve & Pinnularia pulchra Ostrup \\
\hline Pinnularia stauroptera (Grun.) Cleve & Pinnularia stauroptera (Grun.) Cleve \\
\hline Pinnularia viridis Ehr. & Pinnularia viridis Ehr. \\
\hline Stauroneis anceps Ehr. & Pinnularira divergens $\mathrm{W}$. Smith \\
\hline Stauroneis schroederi Hust. & Stauroneis anceps Ehr. \\
\hline Eunotiaceae & Stauroneis schroederi Hust. \\
\hline Eunotia exigua var. bidens Hust. & Eunotiaceae \\
\hline Eunotia monodon var. major fa. bidens (Smith) Hust. & Eunotia exigua var. bidens Hust. \\
\hline Eunotia pecitnalis var. undulata (Ralfs) Rab. & Eunotia pectinalis var. rostrata (Kütz.) Rab. \\
\hline Eunotia pectinalis var. rostrata (Kütz.) Rab. & Eunotia pectinalis var. tetraedron (Ehr.) Ralfs \\
\hline Eunotia pectinalis var. valvaire (Kütz.) Rab. & Eunotia pectinalis var. valvaire (Kütz.) Rab. \\
\hline Eunotia robusta var. tetraedron (Ehr.) Ralfs & Eunotia veneris (Kütz.) Muller \\
\hline Eunotia tenella (Grun.) Hust. & Neidium irridis (Ehr.) Cleve \\
\hline Eunotia veneris (Kütz.) Mull. & Epithemiaceae \\
\hline Neidium binodis (Ehr.) Cleve & Epithemia zebra (Ehr.) Kütz. \\
\hline Nitzschiaceae & Rhopalodia gibba Ehr. \\
\hline Hantzschia amphioxys (Ehr.) Grun. & Nitzschiaceae \\
\hline Nitzschia acicularis Smith & Hantzschia amphioxys (Ehr.) Grun. \\
\hline Nitzschia clausii Hantzsch. & Nitzschia acicularis Smith \\
\hline Nitzschia spectabilis (Ehr.) Ralfs & Nitzschia clausii Hantzsch. \\
\hline Nitzschia subtubicola Smith & Nitzschia fruticosa Hust. \\
\hline Surirellaceae & Nitzschia linearis Smith \\
\hline Surirella ovulum Hust. & Nitzschia subtubicola Smith \\
\hline Surirella tenera Gregory & Nitzschia tryblionella var. levidensis (W. Smith) Grun. \\
\hline Surirella var. splendida Ehr. & Surirellaceae \\
\hline Navicula americana Ehr. & Surirella capronii Brébisson \\
\hline Navicula anglica Ralfs & Surirella molleriana Grun. \\
\hline Navicula cuspidata Kütz. & Surirella ovulum Hust. \\
\hline Navicula grimmei Krasske & Surirella robusta var. splendida Ehr. \\
\hline Navicula laevissima Kütz. & Surirella tenera Gregory. \\
\hline
\end{tabular}

The trend of peak diatom occurrence for both Joysagar and Sitlai Beel were found in March and April (Fig. 1). During these peaks the range of Zs, water temperature, conductivity and SRP for both the water bodies were: $14-15 \mathrm{~cm}, 28.4-30.0^{\circ} \mathrm{C}, 85-129 \mu \mathrm{S} / \mathrm{cm}$ and $56.9-187.7 \mu \mathrm{g} / \mathrm{l}$, respectively. The overall ranges of the above mentioned parameters for both the water bodies were 
Zs: $12-19 \mathrm{~cm}$, water temperature: $21.1-38.4^{\circ} \mathrm{C}$, conductivity: $66.2-129.4 \mu \mathrm{S} / \mathrm{cm}$ and SRP : $25.8-416.3 \mu \mathrm{g} / \mathrm{l}$. This indicates that the diatom peaks occur mostly at medium range values of $\mathrm{Zs}$, water temperature, conductivity and SRP. In contrast, the lowest values of diatoms were recorded in August'96 for Joysagar $\left(1.5 \times 10^{4} / \mathrm{g}\right.$ sediment $)$ and October'96 for Sitlai Beel $\left(30.7 \times 10^{4} / \mathrm{g}\right.$ sediment) (Fig. 1).

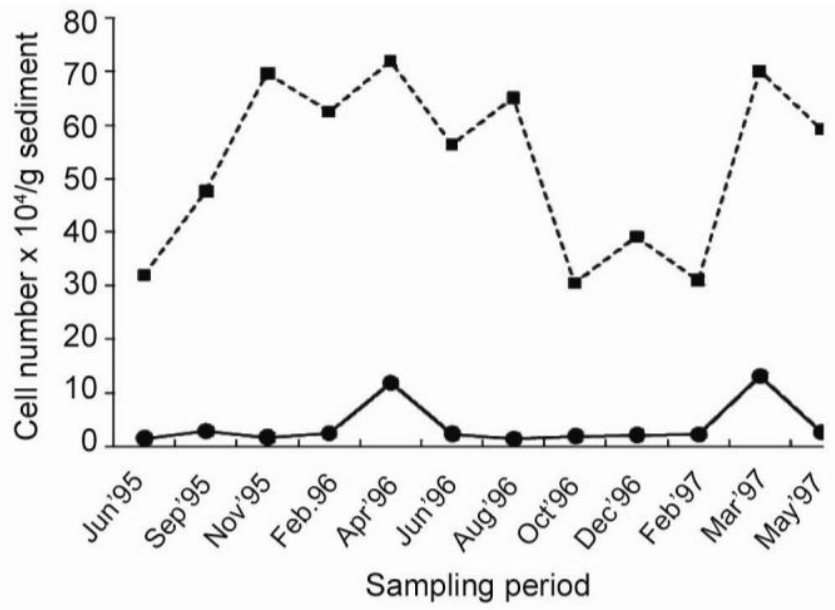

Fig. 1. Seasonal fluctuations of total benthic diatom cells in both of the studied water bodies. --•-- Joysagar, ----- Satlai beel

The eutrophication status of Sitlai Beel is much higher than Joysagar (Table 1). SRS and Ptot are double in concentration and SRP is nearly threefold higher in Sitlai Beel than in Joysagar. Nitrate nitrogen concentration is $30 \%$ more in Sitlai Beel than in Joysagar. On the other hand, pelagic chl. $a$ which is a major limiting factor for the growth of bottom living diatoms is $46 \%$ lower in Sitlai Beel than in Joysagar. Because of these reasons the species number and density of bottom living diatoms are higher in Sitlai Beel.

However, no significant correlation was observed between the SRS concentration of water and the average density of epipelic diatom in both of the Joysagar and Sitlai Beel (Fig. 2A-B). This results contradict with the results of Pearsall (1930), who suggested that the fall in silica concentrations coincides with the diatom maxima and it increases while individual numbers of diatoms decrease. Round (1953) observed 153 fold increases in the concentration of epipelic diatom with a fall of $50 \%$ silicate concentration in the interstitial water. But Hickman (1978) observed relationship between silicate and epipelic diatom within a concentration $0.6-2.8 \mathrm{mg} / \mathrm{l}$. Compared to this range the SRS concentration in both the studied habitats are far more richer (Table 1).

The average concentration of phytoplankton chl. $a$ was higher in Joysagar than in the Sitlai Beel (Table 1). It showed a positive, significant correlation with the density of epipelic diatom of Sitlai Beel (Fig. 2) and it was insignificant in Joysagar (Fig. 2).

The two years of study revealed that diatom flora of Joysagar were dominated by the species of Melosira, Synedra, Navicula, Pinnularia, Gomphonema, and Nitzschia, whereas species of Melosira, Navicula, Pinnularia, Cymbella and Gomphonema dominated the community of Sitlai Beel. Among the dominant species, 11 and 12 species were present in a year round basis in Joysagar and Sitlai Beel. Melosira granulata, Navicula americana, Pinnularia major, and Gomphonema lanceolatum were dominated and expressed distinct seasonality in both the wetlands. 

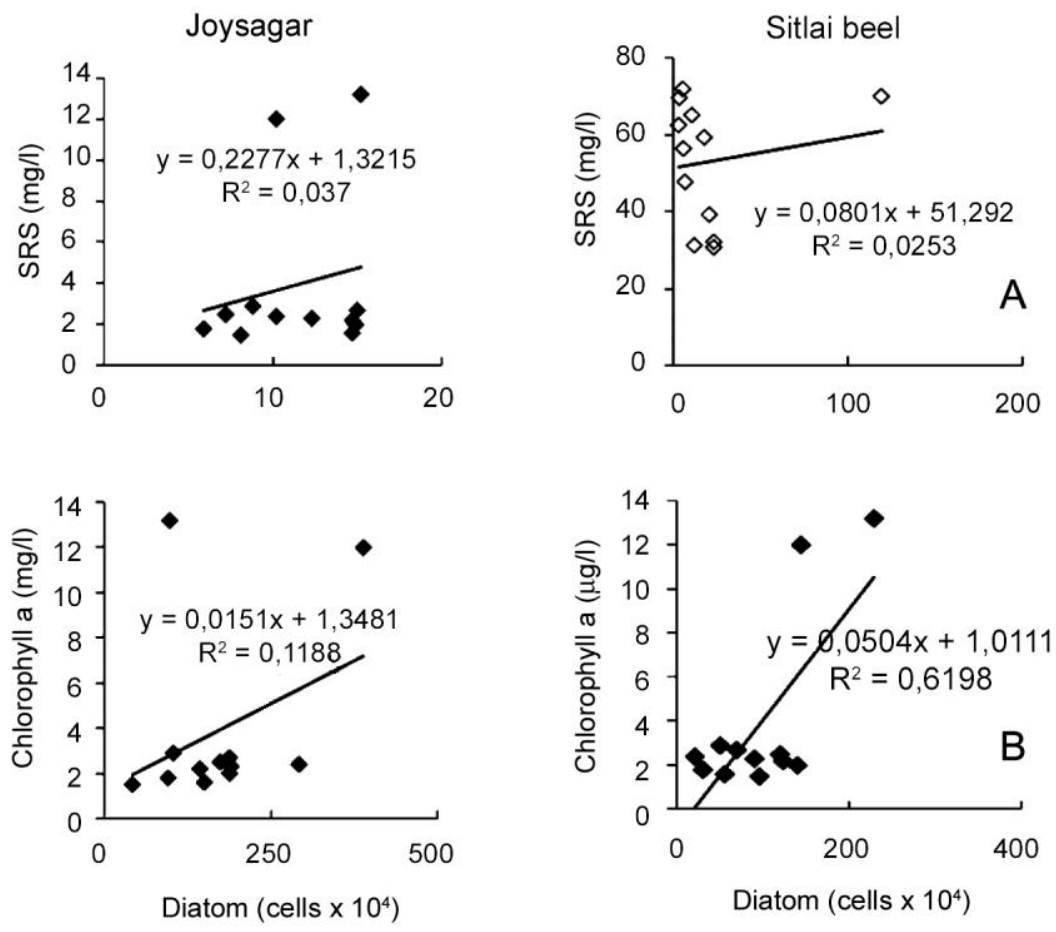

Fig. 2. Relationship of diatom density with chlorophyll $a$ (lower row) and with SRS (upper row) of water of the Joysagar and Sitlai Beel.

The seasonal dynamics of these four diatoms is presented in Fig. 3 A-B for Joysagar and Sitlai Beel. This result is supported by the data obtained by Sherman and Phinney (1971) and Khondker and Dokulil (1987). Sherman and Phinney (1971) made a study on epipelic algal communities of the Metolouis River, Central Oregan. They described that 9 out of 60 identified algal species showed a definite seasonal distribution and remaining species found on a year round basis. The community of downstream was dominated by diatom and mostly were Nitzschia palea and Cymbella cistula. Correspondingly Khondker and Dokulil (1987) observed that the assemblage of epipelic algae was dominated by diatom in a shallow lake, Neusiedlersee, Austria where three species i.e., Cyclotella meneghiniana Kütz., Fragilaria brevistriata Grun. and Nitzschia tryblionella var. levidensis (W. Sm.) Grun. were dominated throughout the year.

In the present study, Melosira granulata was the most dominating species in the epipelic diatom community in the studied wetlands (Fig. 3 A-B). Their density was much higher than the other species throughout the period of investigation. In the first year of investigation, M. granulata showed its highest peak in April $96\left(1.4 \times 10^{4} / \mathrm{g}\right.$ sediment $)$ for Joysagar and in February'96 for Sitlai Beel $\left(41 \times 10^{4} / \mathrm{g}\right.$ sediment). In the second year, an early summer maxima was observed in March'97 $\left(2.4 \times 10^{4} / \mathrm{g}\right.$ sediment $)$ which was much higher than the previous year in Joysagar. In Sitlai Beel, it also showed a summer maxima in March'97, but the cell density $\left(32 \times 10^{4} / \mathrm{g}\right.$ sediment) was lower than the previous year (Fig. 3B). Melosira spp. are economically important for Bangladesh. Islam (1974) analysed the stomach contents of the fish Hilsha (Hilsa hilsa) and cat fish (Mystus aor), and found $98 \%$ of the total food content belonged to Melosira spp. They mainly identified Melosira granulata and some varieties of this species. 
Navicula americana showed four peaks in Joysagar, one in each of November'95, April'96, December'96 and March'97 (Fig. 3 A). In Sitlai Beel the species also showed four peaks but in each of February'96, August'96, December'96 and March'97 (Fig. 3B). This characteristic peak formation for Joysagar and Sitlai Beel has also been observed for two other species namely, P. major and G. lanceolatum (Fig. 3 A-B).
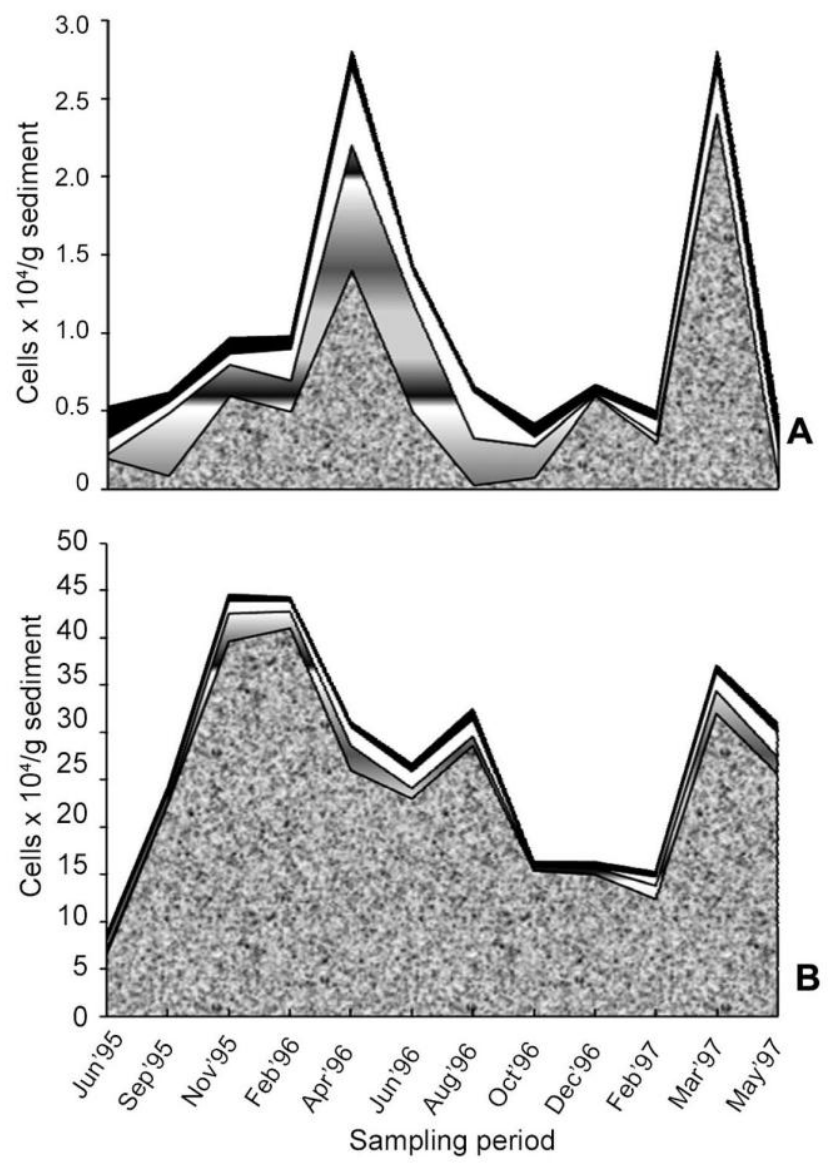

Fig. 3 A,B. Distribution of four major diatom species in Joysagar (A) and Sitlai Beel (B) over the period of investigation. $\square$ M. granulata $\boxminus N$. americana $\square$ P. major $\mathbf{G}$. lanceolatum

From the observations it could be said that, as because of freshwater bio-monitoring requires considerable effort and resources, epipelic diatom has a leading role in many parts of the world (Pan et al. 1999, Leland and Porter 2000). Epipelic diatom assemblages of the studied two wetlands responded to seasonality and environmental gradients; however, different taxa showed different patterns. The diatom population density was much higher in Sitlai Beel than in the Joysagar and the state of SRS concentration of water did not have significant correlation with the diatom density. However, a medium range in the Sechhi disc transparency, water temperature, conductivity and SRP was found suitable for the diatom peaks in the studied wetlands. 


\section{References}

Agatz M., R.M. Asmus and B. Deventer. 1999. Structural changes in the benthic diatom community along an eutrophication gradient on a tidal flat. Helgol. Mar. Res. 53: 92-101.

Amspoker M.C. and C.D. McIntire. 1986. Effects of sedimentary processes and salinity on the diatom flora of the columbia river estuary. Bot. Mar. 29: 391-399.

Barranguet C. 1997. The role of microphytobenthic primary production in a Mediterranean Mussel culture area. Estuarine Coastal and Shelf Science 44: 753-765.

Beltrones S.D.A. and G.V. Romero. 2001. New records of benthic diatoms from natural grazing surfaces of abalone (Haliotis spp.) in the Baja California Peninsula. Oceanides (2): 107-126.

Daume S., S. Brand-Gardner and W. Woelkerling. 1999. Preferential settlement of abalone larvae: Diatom films vs. nongeniculate coralline red algae. Aquaculture 174: 243-254.

Eloranta P. and K. Andersson. 1998. Diatom indices in water quality monitoring of some South-Finnish rivers. Verh. int. Verein. Limnol. 26: 1213-1215.

Federovich S.L. 1980. Diatom Flora of Red Snow from Isbjorneo, Carey oer, Greenland. Nova Hedwigia. Band 33. Braunschweig. J. Cramer. 395-431.

Foged N. 1976. Diatoms from the Alhambra, Granada. Spain. Nova Hedgwigia 27: 881-901.

Germain H. 1981. Flora Des Diatomees, Diatomophycees. Soc. Nouv. Des Edin. Boubee. Paris. 444 pp.

Golterman H.L., R.S. Clymo and M.A.M. Ohnstad. 1978. Methods for physical and chemical analysis of freshwater. Vol. 8. Blackwell Scientific, Oxford. 214 pp.

Hecky R.E. amd R.H. Hesslein. 1995. Contributions of benthic algae to lake food webs as revealed by stable isotope analysis. J.N. Am. Benthol. Soc. 14(4):631-663.

Hickman M. 1978. Ecological studies on the epipelic algal community in five Prairie Parkland lakes in central Alberta . Can. J. Bot. 56: 991-1009.

Hustedt F. 1930. Die Susswasser-Flora Mitteleuropas. Jena. Verlag Von Gusten Fischer. 468 pp.

Islam A.K.M. Nurul 1974. Preliminary studies on the food of some fish. Dacca Univ. Stud. B 22(1): 47-51.

Islam AKM Nurul and AKY Haroon. 1975. Limnological studies of river Buriganga. Dacca. Univ. Stud. Pt. B. 23(1): 25-44.

Khondker M. and M. Dokulil. 1987. Contribution to the systematics of epipelic algae in shallow lake, Neusiedlersee (Austria). Bangladesh J. Bot. 16(2): 181-185.

Leland H.V. and S.D. Porter. 2000. Distribution of benthic algae in the upper Illinois River basin in relation to geology and land use. Freshwater Biol. 44: 279- 301.

Marker A.F.H., C.A. Crowther and R.J.M. Gunn. 1980. Methanol and acetone as solvents for estimating chlorophyll $a$ and phaeopigments by spectrophotometry. Arch. Hydrobiol. Beih.14: 52-69.

Pan Y., R.J. Stevenson, B.H. Hill, P.R. Kaufmann and A.T. Herlihy. 1999. Spatial patterns and ecological determinants of benthic algal assemblages in Mid-Atlantic streams, USA. J. Phycol. 35: 460-468.

Pearsall W.H. 1930. Phytoplankton in the English lakes. I. The proportions in the waters of some dissolved substances of biological importance. J. Ecol. 18: 306-315.

Round F.E. 1953. An investigation of two benthic algal communities in Malham Tarn Yorkshire. J. Ecol. 41: 174-197.

Steinberg C. and S. Schiefele. 1988. Biological indication of trophy and pollution of running waters. Z. Wasser-Abwasser Forsch 21: 227-234.

Tolonen K, M. Liukkonen, R. Harjula and A. Patila. 1986. Acidification of small lakes in Finland documented by sedimentary diatom and chrysophycean remains. In: Diatom and lake acidification, J.P. Smol, R.B. Davis and J. Merilainen (Eds), pp. 171-199. Dr. W. Junk Publishers, Dordrecht.

Underwood G.J.C., J. Phillips and K. Saunders. 1998. Distribution of estuarine benthic diatom species along salinity and nutrient gradients. Eur. J. Phycol. 33: 173-183.

Sherman B.J. and H.K. Phinney. 1971. Benthic algal communities of the Metolius river. J. Phycol. 269-273.

Van Der Werff. 1958. A new method of concentrating and cleaning diatoms and other organisms. Verhandl. In ter. verein Theoret. Angewand. Limonol., Stuttgart. Germany 12: 276-277. 